\title{
Metaplasia in swim bladder epithelium of the endangered annual fish Austrolebias nigrofasciatus (Cyprinodontiformes: Rivulidae) results in inadequate swimming and delayed growth
}

\author{
Alinca Peres da Fonseca ${ }^{1}$, Matheus Vieira Volcan ${ }^{2}$, Luís Alberto Romano ${ }^{1}$ \\ and Ricardo Berteaux Robaldo ${ }^{1,3}$
}

\begin{abstract}
Laboratory breeding of annual fish is often impaired when fish fail to inflate the swim bladder after hatching. These fish, which are known as belly-sliders, cannot swim in the water column, moving mainly on the bottom of water. Therefore, we wanted to understand the factors underlying failed inflation of swim bladder in the annual fish Austrolebias nigrofasciatus and determine the implications of this condition on the growth of juveniles. To identify how the initial filling of the gaseous vesicle is compromised, and to determine the implications of this condition on juvenile growth, we analysed the histology of the swim bladder of both normal swimming fish and belly-sliders during their initial growth phase (first month of life). In addition to slower growth rate compared with fish swimming normally, we found that belly-sliders have metaplasia characterized by epithelium peeling of the swim bladder and the presence of haemorrhage. Based on our findings, it can be concluded that metaplasia of the swim bladder is recurrent in annual fish bred in the laboratory, which explains the large number of unviable larvae. However, its causes remain unknown.
\end{abstract}

Key words: Belly-sliders, Hatching, Killifish, Laboratory breeding, Pathology.

A criação de peixes anuais é frequentemente comprometida pela ocorrência de peixes que não inflam a vesícula gasosa após a eclosão. Estes peixes não têm capacidade de se manter e nadar na coluna d'água e se locomovem no fundo da água, por isso são chamados belly-sliders. Portanto, objetivamos entender os fatores subjacentes à inflação falhada da bexiga natatória no peixe anual Austrolebias nigrofasciatus e determinar as implicações dessa condição no crescimento de juvenis. Para identificar de que forma o enchimento inicial da vesícula gasosa é comprometido, e determinar as implicações desta condição no crescimento dos juvenis, analisamos histologicamente a vesícula gasosa de peixes com natação normal e de belly-sliders durante o crescimento inicial (primeiro mês de vida). Verificamos que os belly-sliders apresentam metaplasia com descamação do epitélio da vesícula gasosa e presença de hemorragia, além de apresentar crescimento mais lento em relação aos peixes com natação normal. Concluímos que a incidência desta patologia é um problema recorrente e de grande relevância para a manutenção de peixes anuais em laboratório, sendo responsável por uma grande quantidade de juvenis inviáveis, no entanto suas causas permanecem desconhecidas.

Palavras-chave: Belly-sliders, Criação em laboratório, Eclosão, Killifish, Patologia.

\section{Introduction}

Annual fish have unique developmental adaptations closely related to their life cycle, making them a good model for comparative studies on development, aging and evolution (Genade et al., 2005; Berois et al., 2014). The breeding of annual fish is often impaired by the occurrence of fish that fail to inflate the swim bladder after hatching (Wourms,
1967; Podrabsky, 1999; Genade et al., 2005; Blažek et al., 2013). These fish, which are known as belly-sliders, cannot swim in the water column and mainly move on the bottom of the water (Wourms, 1967). This is a major problem in the maintenance and management of this group of fish in the laboratory and may complicate efforts at future restocking and recovery of endangered populations, as well as maintaining healthy stocks in the laboratory.

\footnotetext{
${ }^{1}$ Programa de Pós-Graduação em Aquicultura, Universidade Federal do Rio Grande, Estação Marinha de Aquacultura, Caixa postal 474, Cassino, Rio Grande, RS, Brazil. (APF) alincaf@gmail.com, (LAR) dcluis@yahoo.com.

${ }^{2}$ Instituto Pró-Pampa (IPPampa), Laboratório de Ictiologia. Rua Uruguai, 1242. Bairro Centro, 96010-630 Pelotas, RS, Brazil. (MVV) matheusvolcan@hotmail.com, Dhttps://orcid.org/0000-0001-5846-3786 (corresponding author).

${ }^{3}$ Laboratório de Fisiologia Aplicada a Aquicultura, Instituto de Biologia, Universidade Federal de Pelotas, Avenida Eliseu Maciel, 96160-000 Capão do Leão, RS, Brazil. (RBR) ricardorobaldoufpel@gmail.com
} 
Correct initial filling of the swim bladder has a limited window of opportunity, and this physiological requirement will impact the entire life cycle of the fish (Trotter et al., 2001). Fish larvae that do not properly inflate the swim bladder may experience reduced growth (Podrabsky, 1999, Trotter et al., 2001), reduced reproductive capacity (Blažek et al., 2013), and reduced chances of survival, as well as spinal deformities (Kitajima et al., 1994).

Both biotic and abiotic factors are known to influence the initial filling of the swim bladder (Trotter et al., 2003a, 2003b; Woolley, Qin, 2010). Some hypotheses have suggested that the occurrence of belly-sliders in annual fish could be explained by time to hatch the eggs and by management of embryos in the incubation stage (Wourms, 1967; Genade et al., 2005) or physical and chemical characteristics of the water at the time of hatching (Podrabsky, 1999; Genade et al., 2005). However, the etiology leading to the development of belly-sliders instead of normally inflated fish remains to be elucidated. Therefore, this study aims to understand the factors underlying failed inflation of swim bladder in the annual fish Austrolebias nigrofasciatus Costa, Cheffe, 2001 and determine the implications of this condition on the growth of juveniles. Outcomes were expected to provide more insight into management and maintenance of breed stock in the laboratory to conserve this endangered group of freshwater fishes.

\section{Material and methods}

Collection and maintenance of spawners. To collect spawners, a hand net in the shape of a " $D$ " was used. Fishes were collected in wetlands located in the floodplain of the Canal São Gonçalo in Brazil (IBAMA/ICMBio licence No. 41713-1). For the study, a pool of spawners consisting of 70 females and 30 males were maintained in a $200 \mathrm{~L}$ tank with constant aeration. Java moss was used for protection, along with three nests consisting of $2 \mathrm{~L}$ pots with powdered coconut shell as a substrate for spawning. For food, native zooplankton, including cladocerans and copepods, was offered once a day ad libitum. The nests were kept in the tank for seven days, after which the coconut shell was removed and the eggs collected. Using a stereomicroscope, fertilization was verified by the presence of perivitelline space.

Experimental design and procedures. Eight-hundred eggs were selected and separated into groups of 40 units to prevent mortality and contamination. Eggs were kept in $100 \mathrm{ml}$ universal collectors filled with $40 \mathrm{ml}$ of Yamamoto's solution (Arezo et al., 2007; Fonseca et al., 2018). Dead eggs were discarded and the Yamamoto solution was replaced weekly, keeping the viable eggs in these conditions for 30 days. The environment was regulated at $20^{\circ} \mathrm{C}$ and eggs were kept in the dark. Four-hundred embryos were transferred in groups of 40 units each, all in diapause II onto cotton dampened with Yamamoto's solution to 10 universal collectors. At diapause II, embryos have a pulsatile heart and the basic elements of the central nervous system have formed (Wourms, 1967). The embryos were held for another 90 days in airtight jars in the dark until complete embryonic development (diapause III). In this stage embryos are fully formed and ready to hatch (Podrabsky et al., 2010).

Of the 400 eggs kept, 300 in diapause III were selected for hatching. Three groups of 100 eggs each were accommodated in $1 \mathrm{~L} \mathrm{Becker} \mathrm{cups} \mathrm{with} 200 \mathrm{ml}$ of water (chlorine-free tap water) under constant aeration, followed by submersion of $1 \mathrm{~cm}$ of powdered coconut shell. Hatch was checked after four, eight, 24 and 48 hours. Immediately after each observation, the newly hatched fish were separated into normal swimming fish and those struggling to remain in the water column (i.e., belly-sliders). In the following observations, fish that had failed to inflate the swim bladder soon after hatching, but showed normal swimming in subsequent observations, were herein termed "reversed." After hatching, the standard length (SL) of 10 larvae was measured from each swimming class (normal, reversed and belly-sliders) with a digital calliper.

The SL was measured weekly, and two to five fish from each swimming class was randomly chosen for histological analysis.

For histological analysis, the fish were euthanized with an overdose of $3000 \mathrm{mg} / \mathrm{l}$ of eugenol, subsequently fixed in $10 \%$ formalin for 24 hours and then transferred to $70 \%$ ethanol, remaining there for seven days. After this period, specimens were dehydrated in the gradation of alcohol series (80, 90 and $100 \%$ ethanol) and cleared in xylol, soaked in paraffin and made into $5 \mu \mathrm{m}$ longitudinal sections. The sections were mounted on slides, dehydrated, stained with haematoxylineosin and diaphanized in xylene for analysis with an optical microscope equipped with an image capture system.

The representative material of the species used in this study was deposited in the collection of the Coleção Ictiológica at the Universidade Federal do Rio Grande (FURG), voucher number CIFURG 255.

Statistical analysis. To compare SL among swimming classes during the first four weeks of life, two-way ANOVA was used. Subsequently, comparisons were performed with the Tukey test for unequal samples to determine the time course in weeks for which fish of different swimming classes differed significantly in body size, under $95 \%$ significance level, using the Statistica 7.0 program (StatSoft, 2004).

\section{Results}

Of the 300 eggs used for hatching, 123 hatched of these, $16.3 \% \pm 1.9 \%$ swam normally (Fig. 1a), $35.7 \% \pm 4.7 \%$ were reversed, and $48.0 \% \pm 3.8 \%$ hatched as belly-sliders (Fig. 1b) and remained so after 48 hours. All reversed fish began to swim normally within the first 24 hours.

Significant differences were observed in SL among normal fish, reversed fish and belly-sliders (two-way ANOVA; $\mathrm{F}=24.51$, d.f. $=1, \mathrm{p}<0.0001)$ and in SL among the four 

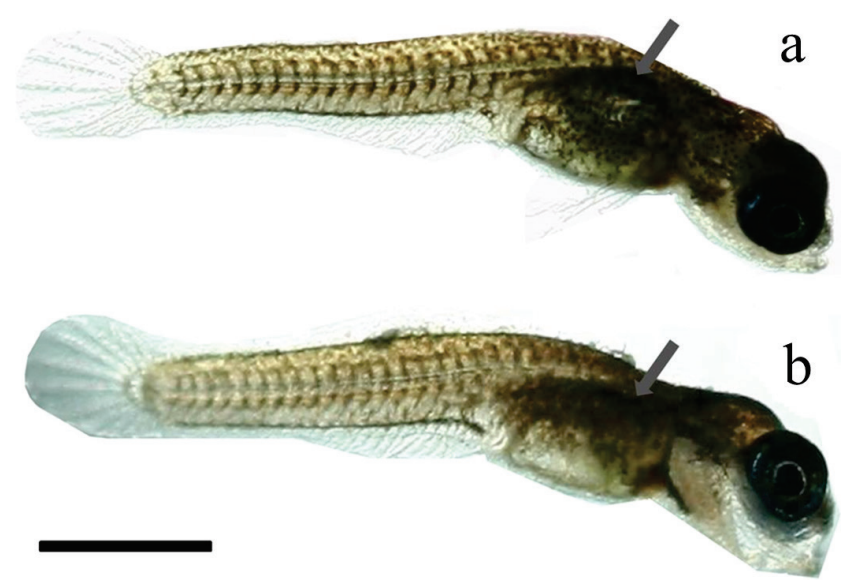

Fig. 1. Newly hatched Austrolebias nigrofasciatus with the inflated swim bladder (a) and with the vesicle not inflated (i.e., belly-slider) (b). Grey arrow indicates location of swim bladder. Scale $=1 \mathrm{~mm}$.

weeks of growth (two-way ANOVA; $\mathrm{F}=54.36$, d.f. $=2$, $\mathrm{P}$ $<0.0001)$. Significant interaction was observed between the two factors, i.e., the four weeks of growth and the three swimming classes (two-way ANOVA; $\mathrm{F}=2.63$, d.f. $=7, \mathrm{P}<$ 0.05 ), indicating that fishes from each swimming class differ in body size as time progresses. Post-hoc comparisons (twoway ANOVA, Tukey, $\mathrm{P}<0.05$, Fig. 2) showed that during the first seven days after hatching, no differences in the SL of fish in the different swimming classes were found; however, from 14 days onwards, belly-sliders showed SL below that of normal or reversed fish (Fig. 2).

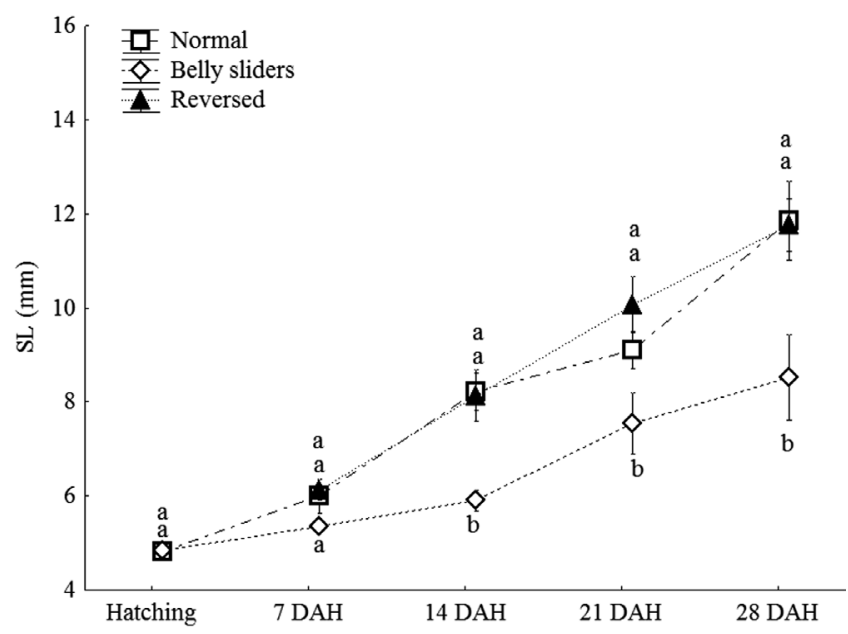

Fig. 2. Effect of the swim bladder dysfunction in the initial growth of Austrolebias nigrofasciatus. Groups: normal fish (inflated bladder), belly-sliders (uninflated bladder) and reverted to the normal condition (reversed). Different letters represent significantly differences between means (Tukey test; $\mathrm{p}<0.05)$.

Histological analysis showed similar morphology in both normal and reversed fish, including swim bladder full of gas
(Fig. 3a). Both normal and reversed fish showed a few squamous cells in the lumen (Fig. 3b) and possible occurrence of sector metaplasia (Fig. 3c), but neither condition appeared to compromise the functionality of the swim bladder.

In contrast, the swim bladders of belly-sliders did not fill with gas, and they exhibited a pathological appearance, with metaplasia of the epithelium of the inner layer peeling and bleeding, causing obstruction of the lumen of the vesicle (Fig. 4). This diagnosis was repeated over time, from hatching to 28 days after hatching (Tab. 1).

Tab. 1. Frequency of occurrence (\%) of metaplasia (Met.), desquamation of the epithelium (Desq.) and presence of erythrocytes indicating haemorrhage (Haem.) in the lumen of the gas bladder (DAH = days after hatching) in normal, reversed and belly-sliders of Austrolebias nigrofasciatus. ${ }^{1}$ Metaplasia present in normal and reversed fish is sectoral and affects only a portion of the swim bladder. ${ }^{2}$ Haemorrhage occurred only in belly-slider fish. $\mathrm{N}=$ number of observation.

\begin{tabular}{|c|c|c|c|c|c|c|c|c|c|c|}
\hline \multirow{2}{*}{ DAH } & \multicolumn{3}{|c|}{ Normal } & \multicolumn{3}{|c|}{ Reversed } & \multicolumn{4}{|c|}{ Belly-slider } \\
\hline & $\mathrm{N}$ & Met. ${ }^{1}$ & Desq. & $\mathrm{N}$ & Met. $^{1}$ & Desq. & $\mathrm{N}$ & Met. & Desc. & Haem. $^{2}$ \\
\hline 2 & 5 & $0 \%$ & $20 \%$ & 3 & $33 \%$ & $0 \%$ & 4 & $25 \%$ & $25 \%$ & $100 \%$ \\
\hline 7 & 3 & $33 \%$ & $0 \%$ & 3 & $67 \%$ & $0 \%$ & 4 & $100 \%$ & $100 \%$ & $100 \%$ \\
\hline 14 & 4 & $50 \%$ & $0 \%$ & 3 & $33 \%$ & $33 \%$ & 5 & $100 \%$ & $100 \%$ & $100 \%$ \\
\hline 21 & 2 & $0 \%$ & $0 \%$ & 3 & $33 \%$ & $0 \%$ & 3 & $100 \%$ & $100 \%$ & $33 \%$ \\
\hline 28 & - & - & - & 4 & $0 \%$ & $0 \%$ & 4 & $100 \%$ & $100 \%$ & $50 \%$ \\
\hline
\end{tabular}

\section{Discussion}

In this study, fish with swimming problems in the water column also showed metaplasia, epithelial descaling, and bleeding of the swim bladder. Many studies report the occurrence of belly-sliders in annual fish (Wourms, 1967; Podrabsky 1999; Genade et al., 2005; Blažek et al., 2013). However, none has thus far attempted to determine the underlying etiology of the swimming phenomena noted above, or which structures are affected. Metaplasia aggravated by swim bladder epithelium desquamation is a very common idiopathic disease that can affect a variety of fish species, involving loss of control over gas discharge and the ability of fish to keep up with neutral column water buoyancy (Roberts, 2012), but it has never been identified in annual fish.

Despite being a frequent pathology, the causes of metaplasia of the swim bladder epithelium are not known to other teleosts, and to the best of our knowledge, only vitamin deficiency from malnutrition has thus far been associated with this dysfunction (Roberts, 2012). Spawners that originated the eggs used in this study were captured from the environment and kept in the laboratory for two weeks before obtaining the eggs. During handling in the laboratory, spawners were fed with native cladocerans and copepods, which, as far as possible, should have provided a balanced diet. However, the possibility of dietary deficiency cannot be ruled out since food resources in the natural environment are known to vary temporally (Keppeler et al., 2014) and thus affect the spawners diet and quality of gametes (Sargent, 1995). 


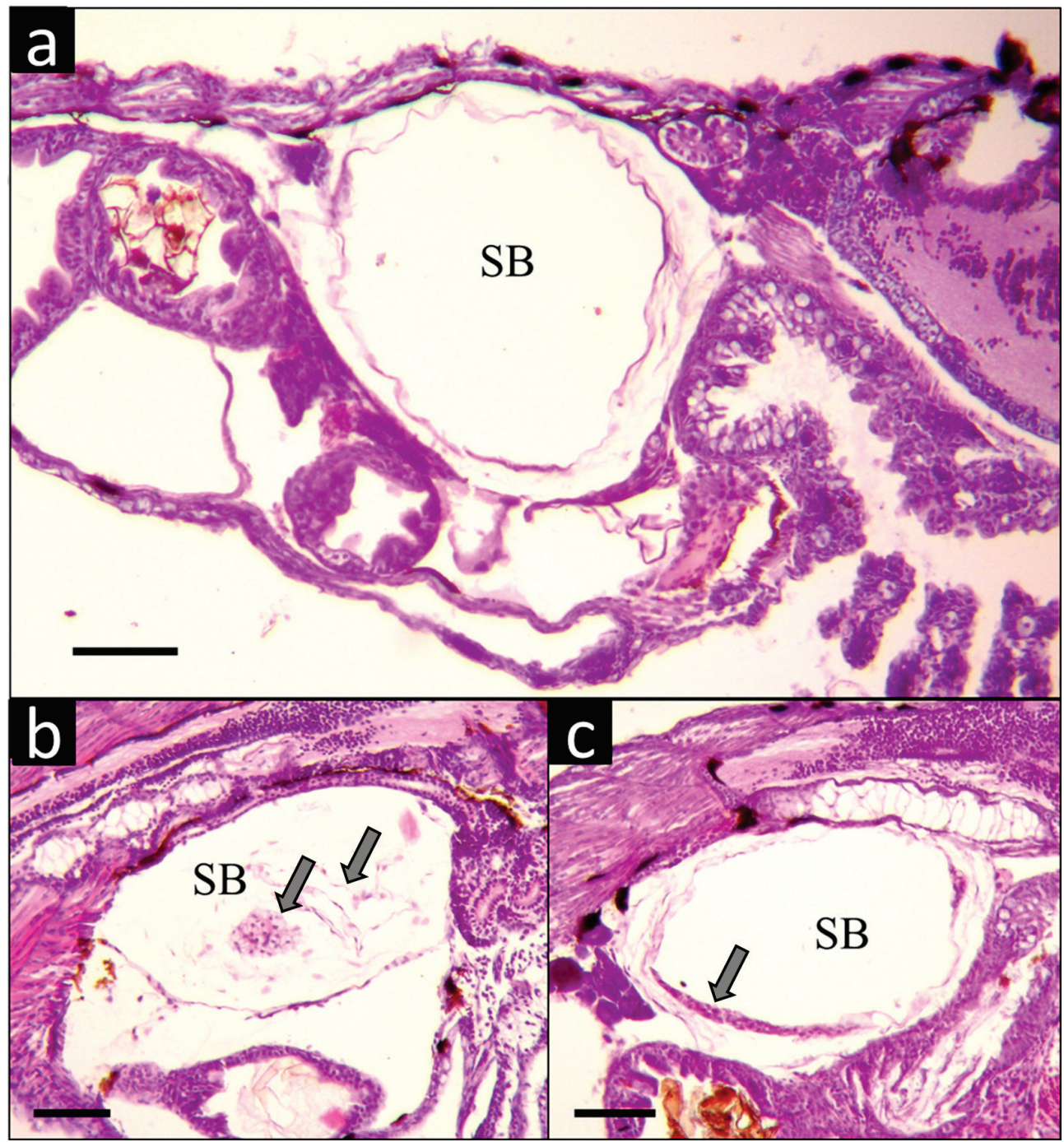

Fig. 3. Histological section (HE) of Austrolebias nigrofasciatus seven days after hatching with the swim bladder (SB) inflated up to 24 hours after hatching. a. SB filled with gas; b. SB inflated and SB desquamated epithelial cells in the lumen (arrows); c. SB inflated with sectoral epithelial metaplasia (arrow). Scale $=100$ micrometres.

Nonetheless, the evidence so far raised for annual fish has never addressed this issue.

Causes other than metaplasia are known to prevent the filling of the swim bladder, such as malformations (Trotter et al., 2001) and infection (Roberts, 2012). However, infections can be secondary to damage that has previously affected the swim bladder, such as ingestion of particles blocking the pneumatic duct (Roberts, 2012). Malformations may also be related to environmental conditions, such as temperature (Trotter et al., 2003a), light intensity and photoperiod (Trotter et al., 2003b), during incubation. In this sense, none of the fish analyzed showed signs of infection or malformation.

Some abiotic factors may affect the health of annual fish, such as the availability of oxygen (Wourms, 1967) and the chemical composition of water (Podrabsky, 1999). Wourms (1967) mentioned that embryos should be incubated in damp conditions, in contact with air, to allow enough oxygen for larvae to inflate the swim bladder in the hours after hatching. According to Podrabsky (1999), irrespective of damp or liquid incubation media, the presence of peat in water can decrease the incidence of belly-sliders, demonstrating that chemical properties of the water have a greater influence on the health of juveniles than the incubation media. According to Genade et al. (2005), prolonged incubation can increase the frequency of belly-sliders, and at hatching, it is necessary to provide peat or peat extract at a depth of $1 \mathrm{~cm}$ of water so that larvae can swim and fill their gas vesicles. Following this hatching protocol, coconut shell was used in all experimental hatching units herein in order to minimize the occurrence of this condition.

In Austrofundulus limnaeus, the swim bladder usually fills immediately after hatching, but it can take up to 24 hours for some fish to begin normal swimming (Podrabsky, 1999). The same was observed with $A$. nigrofasciatus. Specifically, during a 24-hour period of observation, it was possible to 


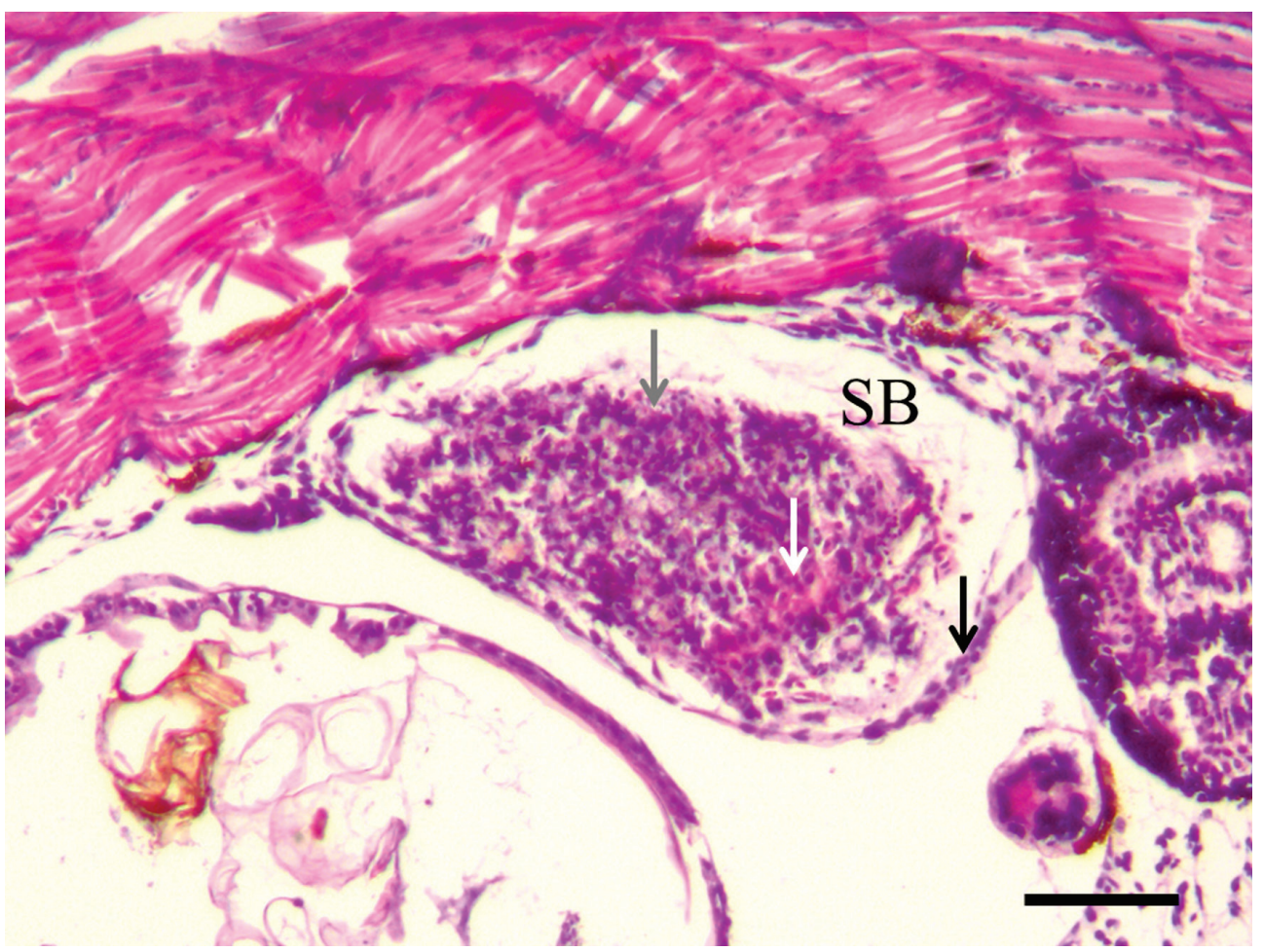

Fig. 4. Histological section (HE) of belly-sliders of Austrolebias nigrofasciatus with uninflated swim bladder (SB) 14 days after hatching. Grey arrow - SB epithelial cells peeling; white arrow - erythrocytes indicating bleeding; black arrow - metaplasia of the SB epithelium. Scale $=100$ micrometres.

identify fish that initially hatched as belly-sliders, but then swam normally, a state which was maintained throughout the study period.

Fish whose swim bladder has not been inflated consume energy to remain in the water column and find it difficult to move about to find food. This, in turn, causes fish affected by metaplasia to show lower growth rate (Woolley, Qin 2010). In this sense, during the initial growth period in our study, SL of the belly-sliders was shorter than that of fish swimming normally. Also corroborating our results, Podrabsky (1999) noted that Austrofundulus limnaeus with uninflated swim bladders are less vigorous and grow more slowly.

The annual fish offers exceptional advantages for studies of genetics, genomics, developmental biology, population dynamics, ecology, biogeography, and evolution (Berois et al., 2017). In addition to their importance as model organisms for field and laboratory studies, most species are in risk extinction (Volcan, Lanés, 2018). Thus, studies aimed at improving the captive maintenance techniques of these species are also fundamental for their conservation (ICMBio, 2013). Based on the observed results, it is concluded that the incidence of disease in the swim bladder is a recurrent problem and is of great importance to the maintenance of annual fish in laboratory conditions, accounting for a large number of embryos that are non-viable or unable to swim normally. Following the discovery of this pathology in the swim bladder, which affects most species of annual fish, future research on the maintenance of these fish in the laboratory should investigate the factors responsible for the incidence of this disease. It is expected that the results of present study can be applied to most annual fish species managed in the laboratory.

\section{Acknowledgments}

Alinca P. Fonseca thanks CAPES for the M.Sc. and Ph.D. grant. Luis A. Romano (301002/2012-6) and Ricardo B. Robaldo (307478/2012-2) are research fellows of CNPq.

\section{References}

Arezo MJ, D’Alessandro S, Papa N, De Sá R, Berois N. Sex differentiation pattern in the annual fish Austrolebias charrua (Cyprinodontiformes: Rivulidae). Tissue Cell. 2007; 39(2):8998. Available from: https://doi.org/10.1016/j.tice.2007.01.004

Berois N, Arezo MJ, De Sá RO. The Neotropical genus Austrolebias: an emerging model of annual killifishes. Cell Dev Biol. 2014; 3(2):136. Available from: http://dx.doi.org/10.4172/21689296.1000136

Berois N, Garcia G, De Sá. A global community effort to decipher the unique biology of annual killifish. Dev Dyn. 2017; 246(11): 807-11. Available from: https://doi.org/10.1002/dvdy.24533

Blažek R, Polačik M, Reichard M. Rapid growth, early maturation and short generation time in African annual fishes. EvoDevo. 2013; 4:24. Available from: http://dx.doi.org/10.1186/2041-9139-4-24

Fonseca AP, Volcan MV, Robaldo RB. Incubation media affect the survival, pathway and time of embryo development in Neotropical annual fish Austrolebias nigrofasciatus 
(Rivulidae). J Fish Biol. 2018; 92(1):165-76. Available from: http://dx.doi.org/10.1111/jfb.13504

Genade T, Benedetti M, Terzibasi E, Roncaglia P, Valenzano DR, Cattaneo A, Cellerino A. Annual fishes of the genus Nothobranchius as a model system for aging research. Aging Cell. 2005; 4(5):223-33. Available from: http://dx.doi. org/10.1111/j.1474-9726.2005.00165.x

ICMBio. Instituto Chico Mendes de Conservação da Biodiversidade. Sumário executivo do plano de ação nacional para a conservação dos peixes rivulídeos ameaçados de extinção. Brasília. 2013. Available from: http://www.icmbio.gov.br/portal/images/ stories/docs-plano-de-acao/pan-rivulideos/sumario-executivorivulideos.pdf.

Keppeler FW, Lanés LEK, Rolon AS, Stenert C, Lehmann P, Reichard M, Maltchik L. The morphology-diet relationship and its role in the coexistence of two species of annual fishes. Ecol Freshw Fish. 2014; 24(1):77-90. Available from: http:// dx.doi.org/10.1111/eff.12127

Kitajima C, Watanabe T, Tsukashima Y, Fujita S. Lordotic deformation and abnormal development of swim bladders in some hatchery-bred marine physoclistous fish in Japan. J World Aquacult Soc. 1994; 25(1):64-77. Available from: http:// dx.doi.org/10.1111/j.1749-7345.1994.tb00806.x

Podrabsky JE. Husbandry of the annual killifish Austrofundulus limnaeus with special emphasis on the collection and rearing of embryos. Environ Biol Fish. 1999; 54(4):421-31. Available from: http://dx.doi.org/10.1023/A:1007598320759

Podrabsky JE, Garrett IDF, Kohl ZF. Alternative developmental pathways associated with diapause regulated by temperature and maternal influences in embryos of the annual killifish Austrofundulus limnaeus. J Exp Biol. 2010; 213:3280-88. Available from: https://doi.org/10.1242/jeb.045906

Roberts RJ. The bacteriology of teleosts. In: Roberts RJ, editor. Fish pathology. Oxford: Wiley-Blackwell; 2012. p.339-382. Available from: http://dx.doi.org/10.1002/9781118222942.ch8
Sargent JR. Origin and functions of egg lipids: nutritional implications. In: Bromage NR, Roberts RJ, editors. Broodstock management and egg and larval quality. Oxford: WileyBlackwell; 1995. p.353-372.

StatSoft, Inc. STATISTICA (data analysis software system). version 7; 2004. Available from: http://www.statsoft.com

Trotter AJ, Battaglene SC, Pankhurst PM. Effects of photoperiod and light intensity on initial swim bladder inflation, growth and post-inflation viability in cultured striped trumpeter (Latris lineata) larvae. Aquaculture. 2003a; 224(14):141-58. Available from: http://dx.doi.org/10.1016/S0044-8486(03)00212-6

Trotter AJ, Pankhurst PM, Hart PR. Swim bladder malformation in hatchery-reared striped trumpeter Latris lineata (Latridae). Aquaculture. 2001; 198(12):41-54. Available from: http:// dx.doi.org/10.1016/S0044-8486(00)00594-9

Trotter AJ, Pankhurst PM, Morehead DT, Battaglene SC. Effects of temperature on initial swim bladder inflation and related development in cultured striped trumpeter (Latris lineata) larvae. Aquaculture. 2003b; 221(14):141-56. Available from: http://dx.doi.org/10.1016/S0044-8486(02)00506-9

Volcan MV, Lanés LEK. Brazilian killifishes risk extinction. Science. 2018; 361(6400): 340-41. Available from: http:// dx.doi.org/10.1126/science.aau5930

Woolley LD, Qin JG. Swimbladder inflation and its implication to the culture of marine finfish larvae. Rev Aquacult. 2010; 2:181-90. Available from: http://dx.doi.org/10.1111/j.17535131.2010.01035.x

Wourms JP. Annual fishes. In: Wilt FH, Wessells N, editors. Methods in developmental biology. New York: Thomas and Crowell Company; 1967. p.123-137.

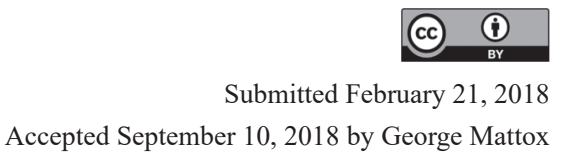

